\title{
Environmental Protection in Strategic Instruments of Spatial Policy in Poland
}

\author{
Ochrona środowiska w strategicznych narzędziach polityki przestrzennej w Polsce
}

\author{
Maciej J. Nowak \\ Faculty of Economics, West Pomeranian University of Technology in Szczecin, Poland \\ ORCID: https://www.orcid.org/0000-0001-8149-8995•macnowak@zut.edu.pl \\ Received: 14 July 2020; Revised: 16 Sep 2020; Accepted: 20 Sep 2020
}

\begin{abstract}
Ensuring environmental protection requires the use of various instruments, including spatial policy ones. Appropriate integration of environmental issues in spatial policy is still a major challenge. The aim of this article is to determine the direction of optimal environmental protection in strategic tools of spatial policy. The article indicates optimal expectations for spatial policy instruments, from an environmental perspective. Then, it verifies the extent to which these expectations are, or can be, included in the current system. The research part verifies studies of conditions and directions of spatial development of voivode cities, in terms of using key elements from an environmental perspective. The analyses and research show that, especially in strategic instruments at the local level, consideration should be given to determining the importance of protected areas in shaping the environment, indicating potential solutions to environmental threats, and the social context of environmental protection. However, attempts at such activities are undertaken, largely, to a very limited extent.
\end{abstract}

Keywords: environmental protection, spatial planning, strategic instruments

Streszczenie: Zapewnienie ochrony środowiska wymaga zastosowania różnych narzędzi, w tym także polityki przestrzennej. Odpowiednie uwzględnienie zagadnień środowiskowych w polityce przestrzennej wciąż stanowi poważne wyzwanie. Celem artykułu jest określenie warunków i zakresu dotyczącego ochrony środowiska, ujmowanych w strategicznych bezpośrednich narzędziach polityki przestrzennej. Wskazano oczekiwania względem narzędzi polityki przestrzennej z perspektywy środowiskowej oraz zweryfikowano, w jakim zakresie oczekiwania te są lub mogą być ujęte w obecnym systemie. Zweryfikowano studia uwarunkowań i kierunków zagospodarowania przestrzennego miast wojewódzkich w zakresie zastosowania kluczowych z perspektywy środowiskowej elementów. Z przeprowadzonych analiz i badań wynika, że zwłaszcza w narzędziach strategicznych na szczeblu lokalnym należy uwzględniać określenie znaczenia terenów chronionych w kształtowaniu środowiska, wskazanie potencjalnych rozwiązań przeciwdziałających zagrożeniom dla środowiska oraz kontekst społeczny ochrony środowiska. Próby takich działań są podejmowane, niemniej w przeważającym zakresie, w bardzo ograniczonym stopniu.

Słowa kluczowe: ochrona środowiska, planowanie przestrzenne, narzędzia strategiczne 


\section{Introduction}

When conducting spatial policies, diverse conditions and requirements, the reconciliation of which is still a significant systemic problem should be considered. In addition to functional, compositionaesthetic, social, or e.g. cultural conditions, there are (as key ones) environmental conditions. Without ensuring environmental protection in spatial policy, it will be impossible to determine (depending on the variant - on a local, regional or national scale) the existence of conditions conducive to sustainable development. Also, in the detailed sphere, it will be difficult to guarantee environmental protection on virtually all other possible levels. Similarly, the lack of an environmental component in spatial policy leads to spatial chaos However, in order for these environmental issues to be correctly included in the spatial sphere, it is necessary to properly apply the tools of spatial policy. Consideration of all significant environmental conditions, when using the indicated tools, is still a serious problem.

The aim of the paper is to determine the direction of optimal environmental protection in strategic direct tools of spatial policy in Poland (study of conditions and directions of spatial development and voivodeship spatial development plans). The analysis is not limited to verifying the current legal status in this respect. It also indicates optimal expectations for spatial policy tools from an environmental perspective and assesses the extent, to which these expectations are or can be included in the current system. Studies of conditions and directions of spatial development of voivodeship cities were also verified in the area of application of key elements from an environmental perspective.

\section{Strategic spatial policy tools}

The notion of spatial policy tools is understood differently in the literature on the subject. The term "instruments" is definitely more often used in this context
- however, referring to them more broadly (e.g. it is pointed out that an instrument in the spatial management system is "spatial planning"). The concept of tools can therefore be more easily referred to specific planning acts and administrative decisions related to spatial policy (assuming their broader than formal understanding). Planning instruments (resolutions of decision-making bodies), administrative decisions and other documents taken by entities of spatial policy (in particular commune, voivodeship and national authorities) aimed directly at obtaining effects in the spatial management system, should be considered direct tools of spatial policy (like in Nowak 2017a, 77-88; Nowak 2019, 79-92). Strategic tools of spatial policy (i.e. not having direct effects in the regulatory sphere) used by local government units include:

- $\quad$ voivodeship spatial development plan;

- study of spatial development conditions and directions.

Of course, the above assumptions are subject to detailed discussion. B. Malisz, referring to contemporary regional plans (studies before 1994 did not apply), emphasized that their main role was to determine the "social, natural-technical and economic-technical" conditions of spatial development of regions (Malisz $1985,108)$. Therefore, land development was distinguished from determining its conditions. These were the foundations of today's understanding of the individual tools' role. The Act of 27 March 2003 on spatial planning and development is criticized in detail (Jędraszko 2005, 19-23; Kowalewski and Nowak 2018, 83-145), among others, for the lack of sufficient protection of spatial order. Nevertheless, it provides for a clear distinction between two categories of planning acts. In this perspective, the basic function of the study should be "determining the spatial development policy of the commune, including local development principles", and the voivodeship spatial development plan has been included in 
"general planning acts" (Niewiadomski 2003, 23, 56).

Broader characterization of the status of both acts requires considering a number of factors, including, but not limited to: the specifics and scope of regional spatial planning, optimal spatial planning model at local level, as well as diverse thematic contexts taken into account in both acts (different, uncoordinated, wording matched to them in the literature). In particular, these functions can be refined in various ways. Here, one may pay attention to: determining (precisely in these acts) the grounds for the implementation of public purpose investments (Gaczek 2003, 89), in a context that guarantees coordination of regulatory acts (especially local spatial development plans), spatial order protection (Śleszyński 2013, 176 -231; Śleszyński et al. 2012, 11-18; Anioł 2019, 54-69; Drzazga 2019, 341-396), as well as integration of development processes (Markowski 2011; Noworól 2013, 85-111; Budner 2019, 176-177; Soja 2009; Faludi 2010; Nadin 2007).

Meanwhile, both the study of conditions and directions of spatial development, as well as the voivodeship spatial development plan are extensive and not always internally consistent acts (Niewiadomski 2016, 81-101). To a different extent (also in terms of level of detail, scope of interference and real direct consequences), their individual parts can be considered. Examples of the above can be the following dilemmas and discrepancies:

- whether and to what extent an individual property owner may have a legal interest in challenging these acts;

- diverse effects of individual parts of voivodeship plans, especially relating to the distribution of public purpose investments and definition of basic elements of settlement networks (Nowak and Mickiewicz 2012, 129-141);

- dilemmas related to the optimal scope of study detail.

Therefore, there is no doubt that in the current formula, the strategic tools of spatial policy are in many respects indefinite and inconsistent, which may also result in the inefficiency of public authorities. However, it can be assumed that their role is to determine (from regional and local perspective, respectively) the basis for further land development, and in exceptional, particularly justified cases - "booking" a specific development formula. The above actions must consider, in particular, the aforementioned guidelines related to key directions and values distinguished in the spatial management system. Both acts are obligatory, therefore the potential problem will be not whether the attempt to perform this function in a given act occurs, but rather how it was undertaken. The key threats include an excessive degree of generality/ ambiguity of individual provisions, as well as their recognition without previously thought-out comprehensive concept for a given area. Environmental protection issues are fully relevant to these dilemmas. Nevertheless, from the perspective of the tools themselves, general dilemmas related to the scope of their application should be emphasized:

- how (in the current system, as well as after its potential changes) to provide optimal protection in strategic spatial policy tools;

- how to guarantee environmental protection both by appropriately shaping the scope of the "environmental" part of spatial policy tools and by direction of their application.

It should also be remembered that there is no one universal direction to solve spatial problems. Here, the specific conditions of individual areas should be widely considered (Albrechts 2006, 1149-1170). Dilemmas occurring in the spatial management system are a classic example of "malicious problems" described by Rittel and Webber (2016, 59-82).

\section{Environmental protection in spatial policy}

There is no doubt that environmental protection is permanently connected to the 
spatial management system. Referring to the Act on Spatial Planning and Development, one can point at least to the main principles distinguished in the spatial management system. In addition to spatial order (the environmental scope of which is also distinguished), there is sustainable development here - primarily understood in this context to the environmental dimension. The legal sphere in this context is primarily about adapting the concept of public interest to this sphere (Fogel 2011, 59-61) and appropriate shaping of the relationship: scope of environmental protection - protection of property owners' rights against unjustified interference (Fogel 2007, 102). This dilemma is first noticeable when regulatory spatial policy tools are used, i.e. local land use plans. However, it must also be included in the strategic tools, the more that they significantly determine the content of regulatory tools. In addition, from a formal and legal perspective, it should also be highlighted:

- differentiation of the scope of the term "environment" (on this issue, e.g. Szulczewska 2008, 57-79). For the purposes of this study, a typical formal and legal approach was adopted, according to which "nature" is a component of the environment, and nature protection occurs in the sphere defined in the regulations as environmental protection, in addition to issues such as air, water, soil protection, etc., protection of agricultural land and forestry, or preventing from damage to the environment;

- diversity of environmental protection tools (nature protection) with particular emphasis on tools assigned to forms of nature protection, also determining the content of strategic tools of spatial policy (Nowak 2013, 89-100, on instruments of environmental protection - Poskrobko 2007, 129-170);

- differentiation of procedures related to environmental protection with particular emphasis on the role of environmental impact assessment, determining the content of most spatial policy tools (Nowak 2017b, 16-17; Nowak 2015, 61-76);

- the role of natural and environmental analyses in the spatial management system with particular emphasis on eco-physiographic studies.

The doctrine tries to answer the question "how to protect natural values?" However, from the perspective of public policy sciences, the key question should be one of the optimal goals related to environmental protection in the spatial management system. Again, as part of providing answers, one can focus on specific areas (even those related to particularly valuable natural areas). The key concept in this context is related to sustainable development and integrated order. It is based on effective management of natural resources, improvement of the quality of modern life and future generations, absolute protection of the highest natural values and stable development, shaping the balance between different spheres (Macias, Bródka 2014, 30). In the latest literature on the subject, this is connected, among others, with the context of potential costs of spatial chaos (Chmielewski et al. 2018, 1115), urbanization of rural areas (Degórska 2017, 87-91), green infrastructure (Giedych, Szulczewska and Maksymiuk 2012, 203-212), ecological corridors (Szulczewska 2004, 56) and green rings (Cieszewska 2019, 17-18).

\section{The scope of strategic spatial policy tools and environmental protection}

The review clearly shows how important is the role of environmental protection in the spatial management system. It cannot be reduced to mere duplication of restrictions resulting from other regulations. Nevertheless, the first thing to look at is the literal wording of the provisions defining the "environmental" scope of voivodeship spatial development plans and studies of spatial development conditions and directions. According to Art. 10 item 1 point 3 of the Act on spatial planning and development, the study considers the conditions resulting 
from the state of the environment, including condition of agricultural and forestry production space, the size and quality of water resources, and environmental, nature and landscape protection requirements, including the cultural landscape. However, in accordance with item 2 point 3 of this article, the study defines areas and principles of environmental protection and its resources, nature protection, landscape, including cultural landscape and health resorts. In item 6 point 3 of the Regulation of the Minister of Infrastructure of April 28, 2004, on the scope of the draft study of conditions and directions of spatial development of the commune, the arrangements for the principles of environmental protection and its resources, nature protection, cultural landscape and spas should include, in particular, guidelines for determining them in local plans resulting from the needs of environmental protection referred to in Art. 72 of the Act of 27 April 2001 - Environmental Protection Law, applicable arrangements for protection plans established for national parks, nature reserves and landscape parks as well as other forms of nature protection occurring in the areas covered by the study project, as well as health resorts referred to in the Act of June 17, 1966, on health resorts and spa treatment. In turn, according to Art. 39 item 3 point 2 of the Act on spatial planning and development, the voivodeship spatial development plan defines the system of protected areas, including those for environmental protection, nature and cultural landscape (the analysis does not include provisions for landscape auditing).

The above statement shows that the largest room for maneuver is contained in the directional part of the study of conditions and directions of spatial development. In voivodeship spatial development plans, areas of environmental protection, nature and cultural landscape are only "determined" and this is based on other acts (the plan itself does not designate such areas). Therefore, this part of the plan can be reduced to an information and ordering function. As indicated by Szulczewska $(2018,176)$, the role of a planner in this scope may be limited to the designation of an ecological network in a given area, but not to introduce restrictions on development (and even the introduction of such does not have any direct effects, which is a certain systemic problem). The scope of studies gives wider possibilities. It is true that the regulation reduces this scope to the future content of local plans, understood strictly in formal law. In general, however, Art. 39 item 3 point 2 of the Act on spatial planning and development is broader. There is also no doubt that the basis for its determination should be environmental analyses (also those related to strategic environmental assessment), but also an eco-physiographic study.

In this context, it is worth paying attention to dilemmas in the commune sphere. They were comprehensively presented by $\mathrm{R}$. Giedych $(2018 ; 148-151,204)$ pointing out the following issues:

- areas included in studies in the context of the environment and nature are treated primarily as areas of conservation of unique ecosystems or habitats of endangered and protected species. Definitely less space is devoted to the importance of protected areas in shaping the environment;

- in some studies - which is good practice - the social significance of protected areas (not only directly understood nature) is emphasized;

- in many cases, including the environmental issues in studies comes down only to creating the right foundation in local plans;

- in current planning solutions, there are no mechanisms guaranteeing the coordination of spatial planning with nature protection.

According to B. Szulczewska (2004, 55), in spatial planning, in the phase of searching for solutions and formulating arrangements of planning acts, particular attention should be paid to: 
- indication of areas with dominant natural trends, the use and development of which must enable them to perform these functions;

- indication of potential building restrictions, including designation of buffer zones for individual areas.

Other observations related to the current scope of the study may be added to the above theses. P. Otawski $(2010,69)$ emphasizes that studies - also in the environmental dimension - have a negligible impact on the use of space. B. Baran-Zgłobicka (2017, 196-197, 310), sharing this point of view, diagnoses difficulties in communication between naturalists and planners as the cause. As a consequence, there is a lack of precise indication in the spatial sphere of determining the directions and scope of harmonious use of the natural spatial and functional structure of the unit, formulating proposals for actions related to minimizing degradation and threats to the natural environment, as well as comprehensively determining the functional and spatial structure based on correctly identified structure of the natural environment. According to the author, the problem here is also the generality of many eco-physiographic studies (similar charges can also be reported regarding the scope of strategic environmental impact assessment - Nowak 2014, 133). B. Szulczewska $(2018,176-177)$ indicates, however, that in the present situation, the maneuver is wider than for voivodeship spatial development plans, which should translate into creating the basis for wider spatial development options in local spatial development plans. And in the area of local plans, there are already broader grounds for restrictions and various options for the development of environmentally valuable areas (Nowak 2013b, 193-205; Nowak and Kiepas-Kokot 2014, 144-163). In addition to the aforementioned elements, this will be limited to determining the biologically active surface of plots.

\section{Environmental provisions for the study of conditions and directions of spatial development in selected Polish cities}

Based on the literature review, key directions covering the environmental sphere have been identified, which should be included in the study of conditions and directions of spatial development. The key (repeated in different approaches) content in literature was indicated, exceeding the formal understanding of the study scope. From this perspective, current studies of conditions and directions of spatial development in voivodeship cities were analyzed. It was assumed that studies in these cities are the most extensive and take into account the broadest perspective (which, of course, is not a rule applicable in every case). For each city, the scale of approaching individual issues was assessed (as part of an individual expert assessment) on a scale of 1-10 (1bad, 10 - very good).

Table 1 verifies to what extent the environmental function (and in particular, its key elements that go beyond the formal and legal sphere) is included in the study of conditions and directions of spatial development of voivodeship cities. It must be stipulated at once that this is not an assessment of the scope of the analyzed urban spatial policy. It is assumed that their diverse spatial and organizational conditions are varied, as well as the varied duration of work on studies or their changes (any lack of specific arrangements will be related to general weakness of the entire spatial management system, and not to the given local context). The point is to verify to what extent individual elements, important from an environmental perspective, are recognized in individual acts. The approach related to the allocation to individual parts of the number of points was proposed (with full awareness of the dilemmas regarding such approach, however, they were considered optimal relating to the specificity of the descriptive part of the studies). The focus was on chapters/parts of studies directly adapted to environmental protection. When 
Table 1. Degree of implementation of the environmental function in the study of conditions and directions of spatial development

\begin{tabular}{|c|c|c|c|c|c|}
\hline City & $\begin{array}{l}\text { Determining the } \\
\text { importance of } \\
\text { protected areas } \\
\text { in shaping the } \\
\text { environment }\end{array}$ & $\begin{array}{l}\text { Indication on how to } \\
\text { minimize potential } \\
\text { threats }\end{array}$ & $\begin{array}{c}\text { Introduction of } \\
\text { potential restrictions } \\
\text { on development }\end{array}$ & $\begin{array}{c}\text { Indication } \\
\text { of the social } \\
\text { significance } \\
\text { of the city's } \\
\text { environmental } \\
\text { values }\end{array}$ & Total, $\%$ \\
\hline Białystok & 5 & 1 & 5 & 1 & 30 \\
\hline Bydgoszcz & 5 & 5 & 10 & 5 & 62.5 \\
\hline Gdańsk & 5 & 5 & 10 & 5 & 62.5 \\
\hline Gorzów & 1 & 5 & 2 & 1 & 22.5 \\
\hline Katowice & 10 & 10 & 8 & 5 & 82.5 \\
\hline Kielce & 6 & 2 & 1 & 2 & 27.5 \\
\hline Kraków & 10 & 5 & 5 & 8 & 70 \\
\hline Łódź & 10 & 5 & 8 & 6 & 72.5 \\
\hline Olsztyn & 1 & 2 & 2 & 1 & 15 \\
\hline Opole & 5 & 5 & 2 & 1 & 32.5 \\
\hline Poznań & 10 & 8 & 10 & 5 & 80 \\
\hline Rzeszów & 8 & 10 & 5 & 1 & 60 \\
\hline Szczecin & 5 & 2 & 8 & 2 & 42.5 \\
\hline Toruń & 5 & 2 & 8 & 1 & 40 \\
\hline Warszawa & 10 & 10 & 10 & 5 & 87.5 \\
\hline Wrocław & 10 & 10 & 8 & 10 & 95 \\
\hline Zielona Góra & 5 & 1 & 2 & 1 & 22.5 \\
\hline $\begin{array}{l}\text { Number of points } \\
\text { obtained / total number } \\
\text { of points }\end{array}$ & $111 / 170$ & $88 / 170$ & $99 / 170$ & $54 / 170$ & 51.7647 \\
\hline
\end{tabular}

Source: Own study

assigning points to individual issues, the following were taken into account:

- whether a given issue occurs in a given extent, even in a marginal way, in a given study (premise to obtain 1 point);

- whether, when specifying individual issues, only the formal and legal formulations or clichés of planning were reproduced, or were the problems referred to in more detail (premise to obtain 5 points);

- whether the approach is a comprehensive description of the problem and how much detail it covers $(8-10$ points).

The reference point for such an assessment is of course the current factual and legal status (with its barriers and manifestations of disability). Table 1 shows that among the elements studied, the importance of protected areas was taken into account to the greatest extent. In the eight cases examined, it can be stated that this issue goes beyond the sphere of defining the indicated areas alone but includes linking them with broader environmental objectives. A larger problem occurred when indicating directions for minimizing the environmental hazards. In general, there was a problem in the studies with a direct approach: they can be found in the four cases studied. Restrictions on development associated with environmental considerations are included more broadly in most of the studies investigated. For the most part, they are not formulated with 
sufficient precision and do not constitute a clear basis for the local plans. However, the social context of environmental protection is considered the least in the studies. Only in three cases, a broader (though not always exhaustive) approach can be found.

When it comes to indicating optimal solutions relating to the first of the examined elements, an example of Kraków can be mentioned. The study defined the city's natural system, diagnosed the detailed basis for its protection, as well as the main directions of its development (including guidelines, e.g. related to the preservation of undeveloped areas - which translates into further parts of the study and then plans). All areas and facilities found in the city were subject to legal protection (from an environmental and natural perspective), individual recommendations were adapted to them as needed, and were characterized in detail, among others, in terms of area or location in Kraków (which translates into further, detailed provisions).

A good example of minimizing the potential threats is a study for Katowice. There is no separate, distinguished section devoted directly to all threats and their reduction, but this thread appears regularly (and exhaustively) in other parts of the "environmental" study directions. An example of such directions may be protection against development of specific areas (e.g. ecological corridors located in the context of further shaping these corridors), minimization of environmental damage at the location of road system elements (by indicating specific solutions), as well as the postulate of renaturalization of some watercourses and their valleys.

An example of a good approach to development restrictions (determined by environmental considerations) could be a study for Warsaw. The Warsaw Nature System with specific areas was precisely identified. In addition to detailed restrictions, general ones were introduced for the entire area - but in terms of duplication, e.g. in local plans. An example of such restrictions may be a ban on location of projects significantly affecting the environment, a ban on making permanent changes in water relations, or indicating elements of specific development of certain areas. Similar rules have also been introduced for areas covered by forms of nature protection. The last criterion distinguished is the least frequently verified in the studied city studies. The content of the study for Wrocław was considered the best view of it. Already at the beginning of the "environmental" part of the directions of this act, it was emphasized how important the environment (in particular green) plays in the functional and spatial structure of the city. Issues of environmental protection in a general and detailed scope have been combined with the social context. In general, this applies to the issue of depopulation of the city center, development of the suburban area and related area transformations. To shape the public awareness was separately highlighted as an important goal. On the other hand, in the detailed scope, reference may be made to environmental protection, related building directions to specific categories of building areas in the city (e.g. block housing, singlefamily housing, etc.). A separate, strongly emphasized direction is shaping within this part of recreational and sports development, in particular, among others, nature and educational paths.

The analysis of the indicated cases entitles to wider conclusions exceeding the dimension of voivodeship cities. Based on previous research and the literature cited above (Nowak 2012, 43-55; Giedych 2018, 148-151) of the subject, it should be assumed that in other communes, the shortcomings of the indicated components are much broader (it was considered that the analysis of case studies would not be representative, but comprehensive analysis of studies from other categories of communes exceeds the scope, even if voluminous, of this work, however, it is an interesting direction for further research, even in groups of valuable natural communes). Studies of conditions 
and directions of spatial development of voivodeship cities, as a rule, contain the broadest analyses of various spatial conditions, and also refer to numerous noticeable and potential spatial conflicts. And the analysis just carried out authorizes the justification of the statements and broader (beyond the mere application of statutory standards) environmental function in the study that can be implemented. In the approach presented above, it is noticeable that studies in this field can create real foundations for further stages of spatial policy.

\section{Conclusion}

Shaping and guaranteeing real foundations for environmental protection in strategic spatial policy tools in the current formula has a limited scope. Voivodeship spatial development plans have only an informative and coordinating role. The formula for the study of conditions and directions of spatial development creates broader possibilities, however, even in the largest cities, key environmental demands (going beyond the formal and legal scope itself) are formulated to a limited extent. Nevertheless, some possible potential for adapting the indicated tools to a broader environmental function is noticeable, as demonstrated by specific case studies. According to the above, the environmental function of studies (in the sphere exceeding formal and legal conditions) should include:

- broader, direct adaptation of the protected areas identified in studies for purposes related to shaping the environment (not stopping at their general separation);

- direct identification of threats to the environment and - equally important - ways to limit these threats;

- formulating the principles of land development in an environmental context in a way that provides a real basis for the local plans, and not (as for many studies) as completely nonbinding general guidelines;

- approach to the social context of the environment, which can be manifested, for example, in developing (adapting to given areas) the concept of green infrastructure, determining the impact of environment on the health of residents, as well as including areas with recreational and sport functions in this context.

It should also be emphasized that strategic tools will not replace regulatory ones. This does not mean, however, that it is possible to sanction the current state of affairs, in which in many cases, a significant part of the views in strategic tools do not constitute a real basis for further actions (and as a consequence, these actions are not undertaken at a later stage). And there is no doubt that the latter - considering the weaknesses of the current spatial planning system - are very much needed.

\section{Bibliography}

Albrechts, Louis. 2006. "Shifts in strategic spatial planning? Some evidence from Europe and Australia." Environment and Planning A 38(2): 1149-1170.

Anioł, Włodzimierz. 2019. Bezład warszawski. O erozji i odnowie przestrzeni publicznych. Warszawa: Elipsa.

Baran-Zgłobicka, Barbara. 2017. Środowisko przyrodnicze $w$ zarzadzaniu przestrzeniq $i$ rozwojem lokalnym na obszarach wiejskich. Lublin: Wydawnictwo UMCS.

Budner, Waldemar. 2019. Gospodarka przestrzenna miast $i$ aglomeracji. Poznań: Wydawnictwo Uniwersytetu Ekonomicznego w Poznaniu.

Chmielewski, Tadeusz, Przemysław Śleszyński, Szymon Chmielewski, i Agnieszka Kułak. 2018. Ekologiczne i fizjonomiczne koszty bezładu przestrzennego. Warszawa: Instytut Gospodarki i Przestrzennego Zagospodarowania PAN.

Cieszewska, Agata. 2019. Green Belts. Zielone pierścienie wielkich miast. Warszawa: Sedno.

Degórska, Barbara. 2017. Urbanizacja przestrzenna terenów wiejskich na obszarze metropolitalnym Warszawy. Kontekst ekologiczno-krajobrazowy. 
Warszawa: Instytut Geografii i Przestrzennego Zagospodarowania PAN.

Drzazga, Dominik. 2019. Systemowe uwarunkowania planowania przestrzennego jako instrumentu osiagania sustensywnego rozwoju. Łódź: Wydawnictwo Uniwersytetu Łódzkiego.

Faludi, Andreas. 2010. "European spatial planning: past, present and future." Town Planning Review no. 21: 1-22.

Fogel, Anna. 2007. “Ochrona przyrody w planowaniu przestrzennym a prawo własności.” W Planowanie przestrzenne - szanse i zagrożenia społecznośrodowiskowe, red. Stefan Kozłowski, i Paulina Legutko-Kobus, 96-105. Lublin: Katolicki Uniwersytet Lubelski.

Fogel, Anna. 2011. Prawna ochrona przyrody w lokalnym planowaniu przestrzennym. Warszawa: Instytut Gospodarki Przestrzennej i Mieszkalnictwa.

Gaczek, Wanda. 2003. Zarzadzanie w gospodarce przestrzennej. Poznań: Oficyna Wydawnicza Branta.

Giedych, Renata, Barbara Szulczewska, i Gabriela Maksymiuk. 2012. "Problemy zarządzania zieloną infrastrukturą miasta na przykładzie Warszawy." Problemy Ekologii Krajobrazu vol. XXXIII: 203-213. Giedych, Renata. 2018. Ochrona przyrody w polityce przestrzennej miast. Warszawa: Komitet Przestrzennego Zagospodarowania Kraju PAN.

Kowalewski, Adam, i Maciej Nowak. 2018. "Chaos przestrzenny i prawo. Uwarunkowania, Procesy, skutki, rekomendacje." W Studia nad chaosem przestrzennym vol. I, red. Adam Kowalewski, Tadeusz Markowski, i Przemysław Śleszyński, 83-145. Warszawa: Komitet Przestrzennego Zagospodarowania Kraju PAN.

Macias, Andrzej, i Sylwia Bródka. 2014. Przyrodnicze podstawy gospodarowania przestrzenia. Warszawa: PWN.

Malisz, Bolesław. 1985. "Gospodarka i polityka przestrzenna.” In Planowanie przestrzenne red. Jerzy Regulski, 59-115. Warszawa: Polskie Wydawnictwo Ekonomiczne.

Markowski, Tadeusz. 2011. „Funkcjonowanie gospodarki przestrzennej - założenia budowy modelu zintegrowanego planowania i zarządzania rozwojem." W System planowania przestrzennego i jego rola $w$ strategicznym zarzadzaniu rozwojem kraju, red. Tadeusz Markowski, i Piotr Żuber,
38-42. Warszawa: Komitet Przestrzennego Zagospodarowania Kraju PAN.

Nadin, Vincent. 2007. “The emergence of the spatial planning approach in England." Planning Practice E Research 22(1): 43-62.

Niewiadomski, Zygmunt. 2003. Nowe prawo o planowaniu izagospodarowaniu przestrzennym. Komentarz. Warszawa: Twigger.

Niewiadomski, Zygmunt. 2016. Planowanie i zagospodarowanie przestrzenne. Komentarz. Warszawa: Beck.

Nowak, Maciej, i Anna Kiepas-Kokot. 2014. "Ograniczenia środowiskowe w instrumentach zarządzania przestrzenią na szczeblu gminnym w województwie zachodniopomorskim." Studia Regionalne i Lokalne nr 4: 144-163.

Nowak, Maciej, i Paweł Mickiewicz. 2012. Plan zagospodarowania przestrzennego województwa jako instrument zarzadzania rozwojem regionalnym. Warszawa: CeDeWu.

Nowak, Maciej. 2012. "Bezpośrednie instrumenty zarządzania przestrzenią na szczeblu lokalnym a rozwój gospodarczy jako problem badawczy." Zarzadzanie Publiczne nr 21(3): 43-55.

Nowak, Maciej. 2013. "Ochrona środowiska jako jeden z celów zarządzania przestrzenią na szczeblu lokalnym i regionalnym." Ekonomia i Środowisko nr 44(1): 193-205.

Nowak, Maciej. 2013. „Wpływ organów parków narodowych na zarządzanie przestrzenią na szczeblu lokalnym." Studia Regionalne i Lokalne nr 53(3): 89-100.

Nowak, Maciej. 2013b. "Ocena oddziaływania przedsięwzięcia na środowisko jako instrument zarządzania środowiskiem w wybranych polskich gminach." Ekonomia i Środowisko 52(1): 56-79.

Nowak, Maciej. 2014. "Strategiczna ocena oddziaływania na środowisko jako instrument zarządzania środowiskiem w wybranych polskich gminach." Ekonomia i Środowisko 48(1): 124-140. Nowak, Maciej. 2015. Decyzja o warunkach zabudowy i decyzja środowiskowa. Warszawa: Beck.

Nowak, Maciej. 2017a. Niesprawność władz publicznych a system gospodarki przestrzennej. Warszawa: Komitet Przestrzennego Zagospodarowania Kraju PAN.

Nowak, Maciej. 2017b. "Restrictions on land use vs. protection of environmental values." Chemistry Environmental Biotechnology no. 20: 15-16. 
Nowak, Maciej. 2019. „Funkcje narzędzi wykorzystywanych w polityce przestrzennej." Studia $z$ Polityki Publicznej nr 23(3): 79-92.

Noworól, Aleksander. 2013. Ки nоwemu paradygmatowi planowania terytorialnego. Warszawa: CeDeWu.

Otawski, Piotr. 2010. "Ochrona środowiska jako wartość i cel planowania przestrzennego." W Wartości w planowaniu przestrzennym, red. Zbigniew Cieślak, i Anna Fogel, 62-73. Warszawa: Instytut Gospodarki Przestrzennej i Mieszkalnictwa.

Poskrobko, Bazyli. 2007. Zarzadzanie środowiskiem. Warszawa: Polskie Wydawnictwo Ekonomiczne.

Rittel, Horst, i Melvin Webber. 2016. "Dylematy ogólnej teorii planowania.” W Governance. Wybór tekstów klasycznych, red. Jerzy Hausner, Bob Jessop, i Stanisław Mazur, 59-82. Warszawa: Wydawnictwo Scholar.

Śleszyński, Przemysław, Tomasz Komornicki, Jerzy Solon, i Marek Więckowski. 2012. Planowanie przestrzenne wgminach. Warszawa: Wydawnictwo Sedno.
Śleszyński, Przemysław. 2013. Propozycja kompleksowej koncepcji wskaźników zagospodarowania $i$ ładu przestrzennego. Warszawa: Komitet Przestrzennego Zagospodarowania Kraju PAN.

Soja, Edward W. 2009. "Regional Planning and Development Theories." In International Encyclopedia of Human Geography, edited by Rob Kitchin, and Nigel Thrift, 259-270. Oxford: Elsevier.

Szulczewska, Barbara, 2018. Zielona infrastruktura. Warszawa: Komitet Przestrzennego Zagospodarowania Kraju PAN.

Szulczewska, Barbara. 2004. „Planowanie przestrzenne jako instrument realizacji sieci ekologicznych: między teorią a praktyką." W Płaty i korytarze jako elementy struktury krajobrazu możliwości i ograniczenia koncepcji, red. Agata Cieszewska, 54-62. Warszawa: Wydawnictwo Szkoły Głównej Gospodarstwa Wiejskiego.

Szulczewska, Barbara. 2008. "Planowanie przestrzenne a ochrona przyrody." W Ochrona przyrody, red. Mirosław Gwiazdowicz, 57-79. Warszawa: Wydawnictwo Sejmowe Kancelarii Sejmu. 